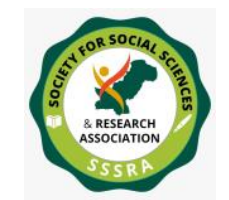

Pak. Journal of Int'L Affairs, Vol 4, Issue 4 (2021) Counter-Terrorism Strategies of the Musharraf ...

\title{
COUNTER-TERRORISM STRATEGIES OF THE MUSHARRAF REGIME IN FATA
}

\author{
Umair Muhammad Khan \\ M. Phil Scholar \\ Department of International Relations \\ University of Balochistan \\ Quetta - Pakistan \\ umairuob78@gmail.com \\ Dr. Fida Bazai \\ Assistant Professor \\ Department of International Relations \\ University of Balochistan \\ Quetta - Pakistan \\ fidabazai456@gmail.com \\ Dr. Ruqia Rehman \\ Assistant Professor \\ Department of Statistics \\ University of Balochistan \\ Quetta - Pakistan \\ ruqia.rehman456@gmail.com
}

\begin{abstract}
Pakistan is a security centric state. It is neither located in Western Europe nor in East Asia to have people-centric and economy centric foreign and domestic policies. South Asia is a difficult political terrain, which does not allow states to focus on other issues at the expense of security, therefore, it is always been the top priority of all South Asian states, especially of Pakistan due to its profoundly dangerous relationship with India, which already converted East Pakistan into Bangladesh in December 1971. There are some experts and political analysts who are critical of Pakistan's foreign policy towards India and Afghanistan. They are of the opinion that Pakistan should focus on economy, poverty, unemployment and lawlessness instead of security. They do not consider geo-strategic threats as real and India as actual enemy of Pakistan. The totally ignore the advice of neo-realists that International system is anarchic, states have to focus on their security to survive in an anarchic international system.




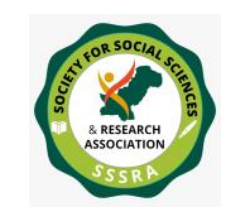

Pak. Journal of Int'L Affairs, Vol 4, Issue 4 (2021) C Counter-Terrorism Strategies of the Musharraf ...

Security threat from India has always been Pakistan's top priority, which has also affected various aspects of domestic politics that includes civil military balance and relationship with non-state actors.

This paper discusses Pakistan's counter-terrorism policy towards the Pakistani Taliban in North and South Waziristan in the Musharraf regime. It covers Pakistan's cooperation with the United States in the war against terrorism during the Musharraf regime. It mainly focuses on the military operations and political deals with the Pakistani Taliban from 2001 to 2007.

Keywords: Counter-Terrorism, Musharraf regime, FATA, Pakistani Taliban.

\section{Introduction}

Pakistan is a security centric state. It is neither located in Western Europe nor in East Asia to have people-centric and economy centric foreign and domestic policies. South Asia is a difficult political terrain, which does not allow states to focus on other issues at the expense of security, therefore, it is always been the top priority of all South Asian states, especially of Pakistan due to its profoundly dangerous relationship with India, which already converted East Pakistan into Bangladesh in December 1971. There are some experts and political analysts who are critical of Pakistan's foreign policy towards India and Afghanistan. They are of the opinion that Pakistan should focus on economy, poverty, unemployment and lawlessness instead of security. They do not consider geo-strategic threats as real and India as actual enemy of Pakistan. The totally ignore the advice of neorealists that International system is anarchic, states have to focus on their security to survive in an anarchic international system. Security threat from India has always been Pakistan's top priority, which has also affected various aspects of domestic politics that includes civil military balance and relationship with non-state actors.

The second challenge to the Pakistani state after the Indian threat is the governance. Pakistan has experienced a number of military coups due to political uncertainty and incompatible leadership since its inception. The last military takeover of the government in order to improve governance was in 1999, when General Pervaiz Musharraf ousted the civilian government of Mian Muhammad Sharif on charges of corruption and plan high jacking on $12^{\text {th }}$ October 1999. Nawaz Sharif and General Pervez Musharraf enjoyed cordial relationship before the incidents of Kargil in 1999. When General Pervaiz Musharraf became Chief Executive of the country, it was already under punitive sanctions from the 


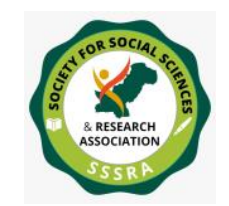

Pak. Journal of Int'L Affairs, Vol 4, Issue 4 (2021) C Counter-Terrorism Strategies of the Musharraf ...

United States due to nuclear explosion on $28^{\text {th }}$ of May, 1998, which had crippled Pakistani economy. The military takeover triggered other democracy related sanctions as well, which totally cut off Pakistani economy from the western markets and it was on the verge of economic collapse. According to the Economic Survey of Pakistan in 2001-02;

Total debt consequently rose from $\$ 20$ billion in June 1990 to a peak of $\$ 43$ billion in May 1998. Pakistan's external debt reached 47.6 per cent of GDP, having grown at an average annual rate of 8.1 per cent throughout the 1990s. The net present value of external debt as a percentage of exports was estimated at 230 per cent in 1998-much higher than the safe limit of 150 per cent. The burden of stock of external debt and foreign currency liabilities rose from 258 per cent of total foreign exchange earnings in 1990 to 364 per cent in May 1998. The ratio of debt service payment due to foreign exchange earnings rose from 23.3 to above 40 per cent in the same period. These ratios clearly suggest that external debt burden had become unsustainable (Hussain, 2008).

When General Pervez Musharraf started consolidating his grip on power to improve governance, there was sudden shift in the international system in form of attack on twin towers in United States on $11^{\text {th }}$ Sepember, 2011, which profoundly affected Pakistan's security dynamics. This incident caused a mass catastrophe in World Trade Centre in New York. This unfortunate incident changed the security dynamics of Pakistan from countering India to counter cross-border terrorism (Christophe, 2002). The United States of America adopted the offensive stance to physically retaliate against the Al-Qaeda, who accepted the responsibility of 9/11 attacks on World Trade Centre. Post 9/11 event changed the geo-strategic environment of the world generally and Pakistan particularly. The US sought assistance from Pakistan to through away terrorist strong havens inside and outside Pakistan. General Pervez Musharraf was asked to work with the US against the emerging threats of Al-Qaeda. Reviewing the regional security paradigm, Pakistan aligned itself with the US by quitting the support of Taliban government. In consequence, Pakistan started acquiring financial support from the US to disperse the threats terrorism. Pakistan's isolation due to nuclear program was ignored by the US and declared it as key ally in the War on Terror against Al-Qaeda and its sub-factions in Pakistan and Afghanistan. According to Economic Survey of Pakistan in 2002.

Notwithstanding the recent "soft take off", the events of September 11 have caused serious difficulties for Pakistan as it has witnessed its exports, imports, industrial production, tax revenue, foreign investment and privatization program badly affected. Its efforts at consolidating the gains of the last two years and taking the economy to a higher growth path have been interrupted. Dawn, 14 ${ }^{\text {th }}$ June, 2002. 


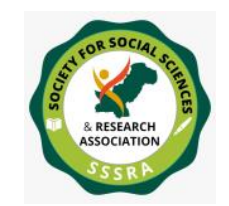

Pak. Journal of Int'L Affairs, Vol 4, Issue 4 (2021) C Counter-Terrorism Strategies of the Musharraf ...

The shift in Pakistan's policy against terrorist groups exacerbated the terror activities of Islamic militant in Pakistan (Naseem, 2007). On a joint forum, the US and Pakistan worked together to share military intelligence, provided air bases for American military operations and allowed the US to conduct drone strikes in its territory. Under the regime of Musharraf, the US paved the way to get a strong alignment with Pakistan to counter the menace of terrorism. General Musharraf had taken various steps externally and internally to improve Pakistan's geo-strategic position in the region that include alliance with the United States, détente with India and access to western markets externally and devolution of Power to introduce local government system, establishment of National Accountability Bureau to arrest corrupt politician, bureaucrat and businessmen in order to improve transparency, and conduct of general referendum to improve legitimacy.

\section{Terrorism in Pakistan}

After the incident of 9/11, the US declared war against terrorism, specifically targeted Al Qaeda and the Taliban. Pakistan was one of the few countries immediately contacted by the US after $9 / 11$ for possible cooperation and intelligence sharing due to its proximity with Afghanistan and cordial relationship with the Taliban. The US Secretary of State Mr. Colin Powell famous phone call of either with us or against us is already widely cited in the literature. In reply, Pakistan decided to join the US, being the target of terrorism for many years. It was considered a suitable option to fight terrorism together with US. The strategic location and the neighbor country to Afghanistan, Pakistan became the front line state in the US alliance against terrorism. Although Pakistan's government faced heavy criticism from public in the form of street protests and agitations, but it continued to be an important partner of the US in the war against the Taliban and Al-Qaeda even at the cost of personal suicide attacks on President Musharraf (Gerson, 2008).

The Taliban government in Afghanistan had also affected the writ of state in tribal areas. The majority of the tribal people along with Taliban were fighting the Northern alliance. Now, the situation was much worse than in the past, Pakistan's support to the US in the war on terror was taken seriously by tribal people due to their security concerns and close relations with Taliban. Al Qaeda, the Taliban and tribal leaders launched an anti-US campaign to motivate the youth of Afghanistan and tribal areas to join them in their fight against the US and its allies. Activists from these organizations assumed a serious terrorist attack at public and governmental organization to undermine and weaken the writ of the government in Pakistan. Even serious efforts were made to gun down President Musharraf twice through miserable attacks, but never succeeded. Finally, Pakistan had to send it military in tribal areas for the first time after independence to establish the writ of government and to restraint the terrorist networks (Hafeez, 2008). 


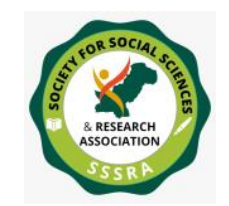

Pak. Journal of Int'L Affairs, Vol 4, Issue 4 (2021) Counter-Terrorism Strategies of the Musharraf ...

\section{Military Operations}

The event of 9/11 and the shift in the United States' policy to declare war against terrorism has profoundly affected Pakistan's geo-strategic position and internal stability. The long and porous border of $2500 \mathrm{Km}$ with Afghanistan has turned Pakistan's tribal areas as the ideal sanctuary for the Al-Qaeda and the Taliban's leadership and remnants. One of the first demands of the United States from the Musharraf regime after breaking up relationship with the Islamic Emirate in Afghanistan was to deploy forces on border to prevent the Taliban and Al-Qaeda members from crossing the border to Pakistan. The PakAfghan border, unlike Pak-India one, was not properly controlled since 1947. There had been free movement of people on the both sides of the border without passing through the proper mechanism of getting visa and fulfilling the requirement of entering another country. The people live on border casually were casually crossing it on daily basis. Convert this border into a fortified one in matter of days after 9/11 was one of the most formidable challenges for Pakistani government. In the Operation Enduring Freedom in Afghanistan, the United States had pressured Pakistan to deploy regular army on the border to stop the movement of people including terrorists, which created security problem on the Pakistani side due to resentment against the government's policy of supporting the US against the Taliban. The Taliban and Al-Qaeda slowly and gradually started capitalizing upon these resentments in tribal areas and finally succeeded in challenging the writ of the state in FATA.

\section{Operation Enduring Freedom}

After the catastrophic event of 9/11, the United States initiated the operation Enduring Freedom against Al-Qaeda and the Taliban in Afghanistan. Pakistan was asked to cordon off the Pak-Afghan border in order to arrest or kill fleeing AL-Qaeda and the Taliban's member to the Pakistan side. The US-Pakistan mutually identified the militants' safe havens and shared intelligence on their where about. The United States stressed on Pakistan to cut off all political, economic and logistic support to the Taliban (Johns, 2010). The United States installed air radar in the air-space of Pakistan to facilitate air supply to the US forces in Afghanistan. Pakistan deployed Frontier Corps, Special Services Groups (SSG) troops and intelligence personnel on border to combat the threats of terrorism and stopped the movement of terrorists from Afghanistan into Pakistan. The joint military cooperation of the US-Pakistan in Operation Enduring Freedom succeeded initially in eliminating Al-Qaeda and the Taliban safe havens initially and arrested and killed thousands of them (Pincus, November, 2008). According to Rand report. 


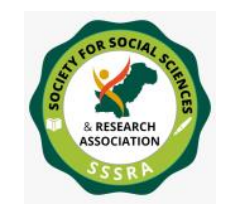

Pak. Journal of Int'L Affairs, Vol 4, Issue 4 (2021) C Counter-Terrorism Strategies of the Musharraf ...

In the end, Pakistan participated in Operation Enduring Freedom in two major ways. First, it permitted over flight and landing rights for U.S. military and intelligence units, allowed access to some Pakistani bases, provided intelligence and immigration information, cut off most logistical support to the Taliban, and broke diplomatic relations with the Taliban.

It further says that.

Second, Pakistan deployed units from the regular army, Special Services Group, Frontier Corps, and ISI to the Afghanistan-Pakistan border to conduct operations along infiltration routes from Afghanistan to Pakistan....In addition, a force of approximately 4,000 Frontier Corps personnel conducted operations in Pakistan's FATA.

Further highlighting Pakistan's contribution in the operation enduring freedom, seth Jones says that.

\section{Operation Al-Mizan}

Operations Al-Mizan was not a single operation conducted on specific date against a particular group, but was a series of cordon, search, arrest and kill activities in North and South Waziristan against the various groups of AL-Qaeda and the Taliban along with the US Operation Enduring Freedom in Afghanistan. Operation Enduring Freedom in Afghanistan led by the US and NATO forces in Afghanistan forced Al-Qaeda and the Taliban members to move to Pakistani side of the border into Federally Administered Tribal areas and other parts of the country. The Taliban and Al-Qaeda members already had contacts with their Pakistani counter-parts, who did not only facilitate their crossing of the border, but also provided shelter and Malmista in order to strengthen their positions in local balance of power in North and South Waziristan. Under strong pressure from the United States after the attacks on the US firebases in Afghanistan, Pakistan started operation Al-Mizan in South Waziristan to arrest and evict foreign militants from the South Waziristan. The operation was aimed to separate international terrorists associated with Al-Qaeda from local population to stop the spread of extremism and terrorism (Shuja, 2009).

One of the major factors for the launch of Operation Al-Mizan was the suicide attacks on President Musharraf in the span of two weeks, when Al-Qaeda leader Ayman al-Zawahiri, had issued Fatwa against Musharraf for cooperation with the United States in Afghanistan and killing of Pakistani forces in South Waziristan. The primary objective was to isolate foreign militants from the local population, but local politics and support for the Al-Qaeda narrative in South Waziristan complicated the job of Pakistan's army. There was no administrative structure in South Waziristan for governance. It was governed by the 


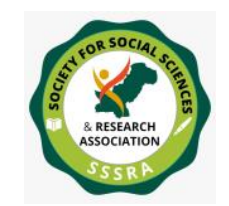

Pak. Journal of Int'L Affairs, Vol 4, Issue 4 (2021) C Counter-Terrorism Strategies of the Musharraf ...

primitive law called Frontier Crimes Regulation; a British time set of rules and regulations for semi-autonomous region based on outdated principle of collective punishment and administration through Malaks.

Operation Al-Mizan, unfortunately, was a total failure as it did not achieve any of its objectives. It was neither based on Counter-Insurgency nor on low intensity conflict. The central government already had a clear idea how North and South Waziristan were turning into hub of Al-Qaeda and the Taliban due to lack of coherent administrative structure. If the government had introduced political and economic reforms and extended the state authority to the greater Waziristan, it would had easily addressed the threat of Talibanisation at the early stages, but nobody including the United States had any idea that Taliban would turn into a Frankenstein and start challenging and attacking the Pakistani state. In 2008 and 2009 the Taliban's insurgency practically started threatening the Pakistani state and there were possibilities that they could occupy major cities like Peshawar after the occupation of Swat and Malakand division, because they were already having sleeping cells and silent support in the settled areas of Pakistan.

During Operation Al-Mizan Pakistan deployed around 80,000 forces in FATA. The FATA was previously administrator by political agent with help of Khasdar, Maliks, and Frontier Corps; Tochi and South Waziristan units. There was no presence of Pakistan's army in the FATA. When the government search and destroy tactic without any coherent strategy for the entire region failed to dismantle Al-Qaeda, it formally asked the political administration of South Waziristan to identify the local harboring foreign militants. According to rand report, "The administration conducted several shuras, consulted maliks, and examined intelligence from local informants to identify over 70 Ahmadzai Wazir tribesmen that were supporting foreign fighters" (p. 47). The forces cordon off the area around the Ahmedzai Wazir's 70 people in Kalosha to arrest and kill Al-Qaeda, but it did not achieve its objective. On $8^{\text {th }}$ January, 2004, when the army was returning from an operation, it was ambushed by the militants. Later on that night Pakistan's army fort in Wana also came under rocket attacks from three sides. There were reports of Al-Qaeda presence in Kalosha area of South Waziristan. It forced the administration to cardon off the area under the control of Commander Nek Muhammad and other 70 members of Ahmedzi wazir tribe. Pakistan used Frontier Corps and XI Crops under the command of Gen: Safdar Hussain.

\section{Operation Kalosh II}

In March 2004, Pakistan's army started a proper military operation in Kalosha against the 70 Ahmedzai families, who were suspected of harboring Al-Qaeda led by Nek 


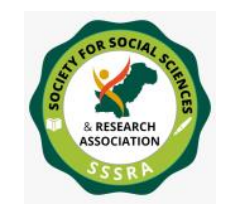

Pak. Journal of Int'L Affairs, Vol 4, Issue 4 (2021) Counter-Terrorism Strategies of the Musharraf ...

Muhammad, Noor-ul-Islam and Haji Muhammad Sharif. General Safdar Hussain was Commander of the XI Corps at the time of Kalosha operation. Pakistani forces faced tough resistance in the various areas surrounding Kalosha, because the militant already had established tunnels and strong network with Ahmedzai tribes. The Operation was initially launched by 700 troops, which had to be increased to 7000 to defeat Nek Muhammad and his colleagues. The operation succeeded in killing several Al-Qaeda members and disrupted its command and control center, but it triggered attacks on Pakistan's army and FC various bases. The operation was later extended to Shakai valley due to reports of AlQaeda members. It succeeded in destroying Al-Qaeda command and control centers, seized sophisticated weapons and equipments and destroyed various tunnels, but did not kill or arrest the top leadership of either Al-Qaeda or the Taliban. According to Seth Jones, Throughout 2004 and 2005, the United States and Pakistan conducted a range of precision strikes against targets, many of which were in North and South Waziristan Agencies. Examples included attacks in the Madakhel Wazir area of North Waziristan in March 2004, Dhog village near Wana in June 2004, the Lawara Mandi area of North Waziristan in July 2004, and Asoray village in North Waziristan in December 2005 (which killed Hamza Rabia, a senior al Qa'ida operative) (p. 50).

When the military operation failed to eliminate Nek Muhammad and his friends, and casualties started mounting in various parts of the agency, the government engaged local politician and influential figures to start negotiation with the Taliban in April 2004. The government constituted a local Jirga consisted of 50 members to negotiate a deal with the Taliban. The Taliban, who had emerged as the most powerful group in greater Waziristan and established their writ by providing security, justice and peace to the local population, achieved a greater level of political legitimacy when the army started negotiation with them. It was the time when Muthida Mujalas Amal (MMA) was ruling the NWFP province. The MMA government and member of national assembly from Waziristan facilitated the agreement between Nek Muhammad and the army, called the Shakai Agreement. The agreement was signed in a Deobandi madrass near Wana, which triggered a lot of criticism in the international media that it was tantamount to surrender to the militants. According to Rehimullah Yusufzai, in Pashtun society when there is conflict between two parties, the final location of the agreement has great significance. Tradiationally, it should take place at a neutral place, but when the two parties are not equal in power then it take place at the home of powerful one to signifies his position in society. It is usually the guilty or weak party that goes to the house of the other one called "Nanawathi" which means seeking forgiveness.

\section{Operation Zalzala}




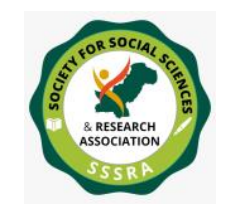

Pak. Journal of Int'L Affairs, Vol 4, Issue 4 (2021) Counter-Terrorism Strategies of the Musharraf ...

Pakistan's strategy toward Waziristan was the product US pressure, the Taliban attack on the army and its position on ground. Whenever pressure was mounting from the United States for military operation to remove Al-Qaeda sanctuaries from FATA, it had started operation; otherwise it preferred a policy of appeasement towards the Taliban based on peace agreements and permission to run parallel administrations in North and South Waziristan. The Taliban were constantly increasing their power by expanding to the other agencies and making alliances with like-minded groups in the rest of FATA. In 2006, there was shift in the insurgency in South Waziristan from Wazir to Mehsud areas. Baithullah Mehsud emerged as leader of the Taliban after the death of Nek Muhammad in a drone strike The Ahmedzai Wazir, who was led by Nek Muhammad and his 70 colleagues, signed an agreement with the Pakistani government after the accession of Moulvi Nazir to power. They had total control over Wana and agreed with the government that would not allow foreigners in their areas. The Mehsud of South Waziristan, who is the largest ethnic group in the agency, started leading the insurgency after the emergence of Baithullah Mehsud. The aim of the operation was to clear area from Baithullah Mehsud's forces. This operation took place when the Taliban did not honour the Sarorogha Agreement signed in February 2005.

In January 2008, the army launched operation Zalzala when Mehsud forces started attacking Pakistan forces and created Tehrik-e-Taliban Pakistan. They captured Sarorogha Fort and declared a vicious war against Pakistan's army by spreading notorious propaganda. The situation reached to a level, when Mullahs refused to offer last prayers of Pakistan's army soldiers. It succeeded in clearing part of the Mehsud area and established check posts on the dominant positions. It displaced roughly 200,000 people. The army in some places applied collective punishment due to a tribe support to the Taliban. It unfortunately, did not reduce the level of violence either in FATA or Pakistan's mainland. 2008 and 2009 were the deadliest years in the Taliban's insurgency. There were $746 \%$ increase in the terrorist attacks from 2005 (Fair, 2009, p174).

\section{Peace Agreements}

Pakistani government did several counter-terrorism military operations in North and South Waziristans since 2001, but it failed to defeat Al-Qaeda and its sympathizers. Waziristan was the ideal location for the Taliban and Al-Qaeda to use as bases against the US forces in Kabul because of its proximity with Afghanistan, support for extremism and loose governance model. There was practically no control of the Pakistani government over the seven tribal agencies, which were ruled through centuries old Frontier Crime Regulation of the British colonial period based on collective punishment. The Taliban intelligently exploited all three mentioned weaknesses in the governance structure in Waziristan and 


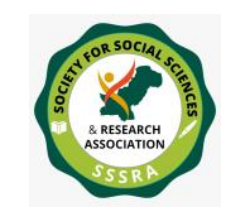

Pak. Journal of Int'L Affairs, Vol 4, Issue 4 (2021) C Counter-Terrorism Strategies of the Musharraf ...

established parallel administration and justice system based on the Afghan Taliban model in 1990s.

The Taliban already had several advantages over the tribal chiefs in the balance of power in North and South Waziristan. They had access to sophisticated weapons, battle hardened foot soldiers, and strong narrative of global cause against the United States in the defense of Islam. The tribal chiefs were having limited support in their tribes, whereas, the Taliban had universal support from lower class unemployed youth, madrasah students, foreign militants, local extremists, Afghan Taliban fled from the other side of the border and some elements of the establishment who had supported them during the Taliban period in Afghanistan. Therefore, the Taliban had replaced the tribal chiefs as the key power actor in the region and emerged as the most powerful group in North and South Waziristan. The Pakistani government had two options at that time. It had to either conduct counterinsurgency operation in 2004 or signed peace agreements to recognize their control over the territory. The Musharraf regime inked the following agreements with the Taliban in South and North America.

\section{Shakai Peace Agreement}

When the Government Kaloshua II operation in Wana against 70 members of the Agmedzai Wazir failed and backfired in term of spread of attacks to other parts of the Wana and mounting of casualties, government approached Jamaiat Ul-lama Islama two parliamentarians from North and South Waziristan; Moulana Merajuddin and Moulana Abdul Malik Wazir as mediator for ceasefire with the militants. This was an unwritten agreement with the militants on $24^{\text {th }}$ April, 2004. This agreement provided militants, financial incentives in return for their disconnection with Al-Qaeda other foreign groups. The deal stressed upon the militant to give up violence in Waziristan and handover foreign militant to the government. This peace agreement was not abided by the militant groups under the leadership of Haji Umar, leader of the Wana Taliban in South Waziristan, as they continued to attack on Pakistan forces. When the Shakai agreement failed in 2004, it was followed by a series of surgical strikes by using air force jet and helicopter gunships against the suspected militants in the Shakai area. Eventually, in June 2004, a US drone strike, killed Nek Muhammad. By then the militancy had already spread from Wana to the Mehsud areas of South Waziristan under the leadership of Baithullah and Abdullah Mehsud.

The Sra Rogah Peace Deal in 2005 


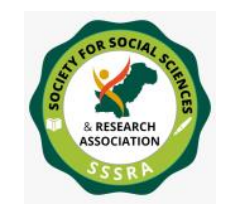

Pak. Journal of Int'L Affairs, Vol 4, Issue 4 (2021) Counter-Terrorism Strategies of the Musharraf ...

When militancy spread to the Mehsud areas in South Waziristan, the military approached Moulana Sirajuddin; a JUI Parliamentarian, to broker a peace deal with the militant in order to bring stability in South Waziristan It was a six point written agreement, in which the Taliban agreed that they agreed to pledge their loyalty to the state of Pakistan and promised to not attack government functionaries, would not shelter AL-Qaeda, and would help the government in order to bring stability in the region. Under the six point of this deal Baitullah Mehsud surrendered himself along with his group members to Jumiat Ulema-i-Islam peace committee. This agreement was not fully followed by militant groups as cross-border unrest and target killing arose. The agreement did not achieve its objective of stability in Mehsud area of South Waziristan rather empowered the militant to further increase their power and declare war on government in South Waziristan (PIPS, 2011) . Asad Durrani called the agreement as strategic mistake and urged the military to involve the civilian administration of South Waziristan in engaging the militants and tribal chiefs as they have better experience of the tribal system in the area.

\section{Peace Agreement in North Waziristan in 2006}

The militancy in Waziristan was not a fixed or rigid phenomenon; it was rather a mobile threat moving from one place to the other. When the United States started targeting AlQaeda and foreign militants in Afghanistan in OEF, they fled to the Pakistani side of the border and took refuge with the Taliban militant of Ahmedzai Wazir in Wana in South Waziristan. When Pakistan's military launched operation Al-Mizan against the Taliban militant in Ahmedzai wazir, they moved to Mehsud areas of South Waziristan under the leadership of Baithullah and Abdullah Mehsud. After the Sra Rogha agreement, the militant activities accelerated in North Waziristan's Gul Bahadur area in Miram Shah. Wazir militants in MiramShah and Mirali Tehsi were active in Afghanistan with the help of the Haqqani network. They totally controlled North Waziristan and killed more than 150 Maliks and pro-government clerics. Pakistan military was also active in North Waziristan and conducted several surgical operations against militant and foreign hide out by killing several of them. Finally Lt. General (retd) Ali Muhammad Orakzai was appointed as Governor of NWFP in May 2006, who orchestrated a peace deal with the militants in North Waziristan on $5^{\text {th }}$ September 2006. There were some reports that a leader of the Afghan Taliban Mullah Dadullah facilitated the peace agreement in North Waziristan in order to focus the Pakistani Taliban on the US forces in Afghanistan (Report, No.125, p18).

North Waziristan was divided among several Taliban leaders; Moulvi Saif ullah, Hafiz Gul Bahadur, Moulvi Shah Jahan, and Hafiz Amir Hamza, who had their little fiefdoms. The agreement did not stop the Taliban from cross-border infiltration. It simply demanded them 


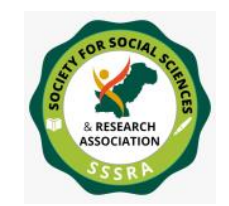

Pak. Journal of Int'L Affairs, Vol 4, Issue 4 (2021) Counter-Terrorism Strategies of the Musharraf ...

to end attacks on the security forces (Asia report, 125, p.18). Governor Orakzai called the deal as historic and unprecedented. The American had strong reservations over the North Waziristan agreement and General James Jones said that attacks in Afghanistan increased after the agreement. Pakistan has avoided major operation in North Waziristan till May 2014 when Army public School incident took place, which called hundreds of school children. The North Waziristan was managed through peace deals and some surgical strikes and US drone strikes. The major disagreements between Pakistan and the United States on fundamental issues did not allow the later to launch comprehensive counterinsurgency operations in either North or South Waziristan.

\section{Conclusion}

The Office of the political agent was the supreme authority in the area, which had judicial, executive and financial power and was not responsible to any institution that created power vacuum and encouraged tribes to resolve their problems at the tribal level rather appealing to the state for service deliveries and conflict resolution. The Taliban with the help of AlQaeda and their Afghan counter-parts already replaced tribal chiefs and emerged as the most powerful actors at the agency level. They started delivering services to people through speed justice and maintained law and order through strict implementation of Sharia, which gained local support among people due to lack of economic opportunities, unemployment and corruption. The militants had established their little emirates in South and North Waziristan based on the Taliban model in Afghanistan. The United States pressured Pakistan to dismantle the Taliban's empire in greater Waziristan by particularly stressing upon the removal of Al-Qaeda's leadership, which had declared Waziristan as headquarter. The US had provided $\$ 2$ billion as coalition support fund to the Pakistani Government in order to meet the expenses of operation Al-Mizan (Ahmed, 2014.).

The objective of the Shakai agreement with the Taliban was to install normalcy and avoid any major counter-insurgency operation, but it did not achieve any of its targets rather increased the support and legitimacy of the Taliban. When the government and the Taliban made a Shakai agreement, it discouraged local people, who were anti-Taliban to assist the government, because they realized that the government could not provide them security against the Taliban. After peace agreement in Shakai in March 2004, the Taliban started a ruthless assassination campaign against the pro-government Maliks, who were the only obstacle in the Taliban dominancy of Waziristan. If the Pakistani government had protected tribal chiefs from the Taliban and made an alliance with them, it would have achieved far greater success against the Taliban and Al-Qaeda in the early stages.

In a tribal society, legitimacy, ideology and perceptions are important components of power. The Taliban already achieved power in Waziristan even during the Taliban 


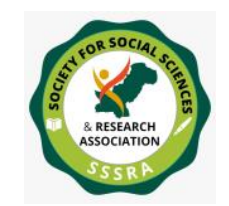

Pak. Journal of Int'L Affairs, Vol 4, Issue 4 (2021) Counter-Terrorism Strategies of the Musharraf ...

government in Afghanistan before 9/11. They also got extra weapons and resources in the form of Al-Qaeda and Uzbek militants after the fall of the Taliban's regime. The entry of militants totally changed the political landscape of the area, which would not have been possible if there was a solid coalition between the army and local Malak, but it did not happen. Ideology was also provided in the form of Jihad when the US forces occupied Afghanistan and declared a war against Islam. There is not any stronger ideology than Jihad in Waziristan. The last ingredient; perception, was provided by the peace agreement, especially in Madrasah. The Shakai agreement took place in a local Madrasah, which immensely increased the legitimacy of the Taliban as the most powerful actor and winner in the war with the army. If the agreement had taken place in the office of the army's local commander, it would have decreased the Taliban's local stature.

A range of military operations in North and South Waziristan could not change the militant landscape of the area. The Maliks and elders, who were the real stake-holders and administrator, were defeated by the Taliban due to their sweeping power with assistance of Al-Qaeda and foreign militants. The Taliban in Waziristan were far more superior to the Malik's lashkars and government Khasdar forces due to their larger number, sophisticated weapons, highly motivated foot soldiers and battle hardened experiences in Afghanistan. Counter-insurgency operations at the early stages would have protected Waziristan from the Taliban, but lack of army experience in Waziristan made it extremely difficult terrain for counter-insurgency operations.

Pakistan's army did not have any basic information about the area. They have never visited the area. The information were of superficial level, whereas, the Taliban on the other hand had the support of complete tribes in some places. For example, the entire Ahmedzai Wazir in Wana initially supported Nek Muhammad against the Pakistani army for three reasons. Firstly, it was conceived that Pakistan was fighting the US war in Waziristan, which created widespread resentment in the area due to US bombardment in Afghanistan. Secondly, Pakistan army had never visited the area and did not have any network in the region. Whereas, the Taliban had been using Waziristan long before for Jihad in Afghanistan, so it was already a popular concept in the tribal people. Thirdly, Nek Muhammad was considered a fellow Wazir brother against the army, which is largely constituted of non-tribal people. According to W Aslam, "The FATA territories have seen significant changes since the onset of the Afghan jihad launched in the aftermath of the Soviet invasion of the country in 1979, due to the religious nature of the anti-Soviet struggle" (p. 5, 2020).

The Musharraf regime policy towards the Taliban and Al-Qaeda in North and South Waziristan was the result of American pressure, lack of popular support in FATA, surgical 


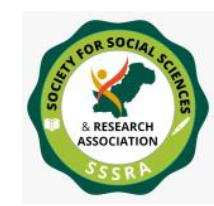

Pak. Journal of Int'L Affairs, Vol 4, Issue 4 (2021) Counter-Terrorism Strategies of the Musharraf ...

low intensity strike called military operation, peace agreements, and lack of confidence with the political administration and tribal chiefs. The military establishment conducted operations not on the basis of local intelligence about the presence of Al-Qaeda and foreign militants, but due to strong pressure from the United States to eliminate Al-Qaeda's remnants. Pakistan could not resist the pressure because of the cordial relationship between the Musharraf regime and Bush administration. Secondly, Pakistan did not conduct counter-insurgency operation, because it was neither the demand of the US nor in the interest of Pakistan. It simply conducted surgical strikes and counter-terrorism operations in some pockets against the local militants who were harboring foreign militants. When counter-terrorism operation backfired, the military resorted to peace agreement, which is a traditional mechanism of conflict resolution in FATA. Thirdly, there was lack of coordination between the civilian administration and tribal chiefs in Waziristan and military commanders. The military commanders did not take local political administration and tribal chiefs either at the time of operations or peace agreements. If there was a coordinated policy towards the Taliban of the military commanders, political administrations and local tribal chiefs, it would have produced better results. 


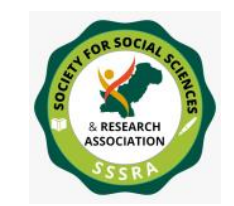

Pak. Journal of Int'L Affairs, Vol 4, Issue 4 (2021) Counter-Terrorism Strategies of the Musharraf ...

\section{References}

Ahmed Rashid. (2000). Taliban: Militant Islam, Oil and Fundamentalism in Central Asia. London: . Yale University Press.

Ahmed, N. (2014.). Pakistan's Counter Terrorism Strategy and its Implications for Domestic, Regional and International Security.

Ahmed, Z. S. (2009). Madrasah Eduction in the Pakistani Context, Challenges, Reforms and Future Directions . South Asian Journal of Peace building .

C, C. (2008). Fair, the Madrassah Challenge: Militancy and Religious Eduction in Pakistan . Washington DC United States Institute of Peace Press .

Cheema, P. I. ( "Challenges Facing a Counter-Militant Campaign in Pakistan"s). "Challenges Facing a Counter-Militant Campaign in Pakistan"s FATA .

Christophe, J. (2002). A History of Pakistan And Its Origin. Anthem Press.

Cohen, S. P. (2003). The Jihadist Threat to Pakistan. The Washington Quarterly.

Gerson, J. (2008). The US War in Afghanistan: Goals, Future, and Alternatives. International Afghanistan.

Hafeez, M. (2008). US Relations with Afghanistan and Pakistan. the Imperial Dimension .

Hafiz Muhammad Inamullah, H. H. (2010). Reforming the Madrassah System of Education in Pakistan. Contemporary Issues in Education Research .

Hakim, R. (2005). A Game of Nerves. New Line.

Hasanie, A. (2013). Democracy in Pakistan: Crisis, Conflict and Hope for Change. .

Iram Khalid, M. I. (2016). Pakistan's Military Operations: the Counter terrorism Strategy (2001-2013) Prospects and Implications. JRSP.

Johns, S. G., \& Fair, C. C. (2010). Counter Insurgency in Pakistan. Rand Corporation. 
$\underline{\text { Pak. Journal of Int'L Affairs, Vol 4, Issue } 4 \text { (2021) Counter-Terrorism Strategies of the Musharraf ... }}$

Khan, H. (2001). Constitutional and Political History of Pakistan. Oxford University Press

Khan, J. K. (2014). Combating Militancy: A Case of Pakistan Military Operations. British Research Institute.

Khan, M. A. (2009). A Profile of Militant Groups in Bajuar Tribal Agency. Terrorism Monitor .

Khan, S. (2008). Behind the Crises in Swat. The News.

Laurent, B. N. (2010). Counter- Insurgency Lessons Old and New: A Practical Guide.

Musharraf, P. (2006). In the Line of Fire. A Memoir.

Naheed., G. S. (2013). Afghan-US Relations and its Impact on Pakistan. University of the Punjab.

Naseem, S. (2007). The Unraveling of the 9/11 U- Turn. Pakistan Economy and Polity in a South Asia Perspective.

"Pakistan's Tribal Areas: Appeasing the Militants," International Crisis Group, Report, 11 December 2006.

Pincus, R. C. (November, 2008). “U.S. Seeks New Supply Routes into Afghanistan. The Washington Post.

Report, I. C. (n.d.). Pakistan's Tribal Areas: Appeasing the Militants,. 2006.

Rubin, E. (2002). Can Musharraf Reform Jihadi Cutlure? Christain Science Monitor.

Satti, Z. (2008). National Strategy for Fighting Terror. The News.

Sehgal, I. (2008). Concept of National Security. The News.

Shuja, N. (2009). FATA: a Most Dangerous Place Meeting the Challenges of Militancyand Terror in the Federally Administered Tribal Areas of Pakistan. Center for Strategic and International Studies.

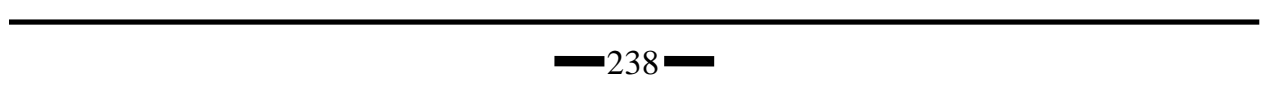


Pak. Journal of Int'L Affairs, Vol 4, Issue 4 (2021) Counter-Terrorism Strategies of the Musharraf ...

Tipu, M. I. (2014). The South Waziristan Agency. Center of International and Strategic Analysis. 